\title{
Fish Fauna of Kurikotta Bridge Bennithora River, Gulbarga District of Karnataka, India
}

\author{
K. Ravikiran*, R. S. Kulkarni, Sharanappa Padashetty \\ Department of Post Graduate Studies and Research in Department Zoology, \\ Gulbarga University Gulbarga - 585 106, Karnataka, India \\ *E-mail address: ravikirankattimani@gmail.com
}

\begin{abstract}
The present study deals with the fish fauna of Kurikotta Bridge Bennithora River, Gulbarga district of Karnataka. The study was undertaken for a period of one year and monthly collections were made from April-2013 to March-2014, in four sites. The result of present study reveals the occurrence of seventeen (17) fish species belonging to five orders. The order Cypriniformes was dominant with nine (9) followed by order Siluriformes (4) Channiformes (2), Mastacembelidae and Osteoglossiformes each with one species.
\end{abstract}

Keywords: fish; fauna; Kurikotta; Bennithora River

\section{INTRODUCTION}

India is one of the megabiodiveristy countries in the world and occupies the ninth position in term of freshwater megabiodiveristy (Mittermeier and Mittermeier, 1997). Fishes have been used since time immemorial for a number of purposes, the most basic being food. Both marine as well as freshwater ecosystems have been exploited by all civilization for thousands of years. A major part of the economy of many countries thrives on the exploitation of this resource. In addition fishes also serve other purposes as a medicinal source for a number of aliments, as decorations in aquaria, which have been commercialized to large extent in the recent times.

Due to these multiple uses of fisheries resources, fishing has become a major industry and a large number of these aquatic communities are under a big threat of extinction. In addition human alternation of many of the fish habitats (e.g., conversion of wetlands for cultivation natural tanks for irrigation for land filling, rivers for dams and hydroelectric power) has also lead to the disappearance. There is an urgent need to understand this alarming situation and try to provide mitigation measures in order to prevent the possible loss of the groups of organisms (Vijaylaxmi, 2010).

Considerable studies on the ichthyofaunal diversity have been carried out during the last few decades (Day, 1967). In present study an attempt has been made to highlight the fish fauna of kurikotta bridge Bennithora River. The work will provide future strategies for development of fish species conservation and it is the first effort in this direction. 


\section{MATERIALS AND METHODS}

\section{1. Study area}

Bennithora River rises on the ridge near the village of Malegaon in Maharashtra state and enters Gulbarga district near Hipperga village in Aland taluk. It forms the boundary between Gulbarga and Bidar district for about 6 to $8 \mathrm{~km}$ and flows generally in the north easterly direction in joint the Kagina river on its right bank near Malkhed. The total length of the river in Gulbarga district is about $96 \mathrm{~km}$. the river flows in Aland, Gulbarga and Chittapur taluks. There is a bridge across this river on the Gulbarga-Humnabad road near Kurikotta village in Gulbarga taluka. Another bridge across this river on the Mahagaon Kadaganchi road, near kamalnagar village in Aland taluk, is under construction. The study area of kurikotta bridge Bennithora river.

\section{2. Sampling}

The present work is an attempt to study fish fauna of kurikotta bridge Bennithora river. Fishes were collected from different selected localities with the help of local fisherman using different types of nets namely gill nets, cast nets and dragnets. Immediately photographs were taken prior of preservation with $10 \%$ formalin, since formalin decolorizes the fish colour on long preservation.

Fishes brought to the laboratory were fixed in formalin solution in separate jars according to the size of species small fishes were directly placed in formalin solution, while larger fishes were given an incision on the abdomen before they were fixed. The fishes collected and fixed were labeled giving serial number, exact locality from where collected data to the collection. The common local name of fish used in this region was labeled in each jar containing the fish. Identifications were done based on keys of fishes of the Indian subcontinent (Day, 1958, Jayram, 1981, 1999, Talwar and Jhingran, 1991). Classification was carried out on lines of Day (1889), Nelson (1976) and Jayaram (1981). The identification of the species was done mainly on the basis of the colour pattern, specific spots or marks on the surface of the body shape of the body structure of various fins etc.

\section{RESULTS AND DISCUSSION}

The results of present investigation confirmed the occurrence of seventeen fish species belonging to five orders at Kurikotta Bridge Bennithora river collected over a period of one year, from April-2013 to March-2014. The distribution of fish species is quite variable because of geographical and geological conditions.

Order Cypriniformes with nine (9) species, Labeo rohita (Hamilton, 1822), Labeo boggut (Sykes, 1839), Labeo fembriatus (Bloch, 1797), Osteobrama cotio cotio (Hamilton, 1822), Puntitus sarana (Hamilton 1822), Puntitus lithopidos (Day, 1874), Mystus seenghala (Skykes, 1839), Salmostoma baccaila (Hamilton, 1822), Aurichtys seenghala (Sykes, 1841). Order Siluriformes with four (4) Mystus bleekeri (Day, 1877), Mystus gulio (Hamilton, 1822), Ompok pabda (Hamilton 1822), Ompok bimaculatus (Bloch, 1794), Order Channiformes with two (2) Channa striatus (Bloch, 1994), Channa punctatus (Bloch, 1794).

Order Mastacembeliformes and Osteoglossiformes with one each species Mastacembellus armatus, Notopterus notopterus. 
The order Cypriniformes was dominant with nine (9) species followed by order Siluriformes with four (4) Channifomes with two (2) and Mastacembeliformes and Osteoglosssiformes each with one species. Seventeen fish species representing by five orders.

Table 1. Showing fish fauna of Kurikotta bridge Bennithora River, Gulbarga District.

\begin{tabular}{|c|c|c|}
\hline \multirow{11}{*}{ I } & Order: & CYPRINIFORMES \\
\hline & Family: & Cyprinidae \\
\hline & Species: & Labeo rohita \\
\hline & & Labeo boggot \\
\hline & & Laeo fembriatus \\
\hline & & Osteobrama cotio cotio \\
\hline & & Puntius lithopidos \\
\hline & & Puntius lithopidos \\
\hline & & Mystus seenghala \\
\hline & & Salmostoma bacaila \\
\hline & & Aurichtyes seenghala \\
\hline \multirow{6}{*}{ II } & Order: & SILURIFORMES \\
\hline & Family: & Bagridae \\
\hline & Species: & Mystus bleekeri \\
\hline & & Mystus gulio \\
\hline & & Ompak pabda \\
\hline & & Ompak bimaculatus \\
\hline \multirow{3}{*}{ III } & Order: & CHANNIFORMES \\
\hline & Family: & Channidae \\
\hline & Species: & Channa striatus \\
\hline & & Channa punctatus \\
\hline \multirow[t]{3}{*}{ IV } & Order: & MASTACEMBELIFORMES \\
\hline & Family: & Mastacembelidae \\
\hline & Species: & Mastacembellus armatus \\
\hline \multirow[t]{3}{*}{$\mathbf{V}$} & Order: & OSTEOGLOSSIFORMES \\
\hline & Family: & Notopteridae \\
\hline & Species: & Notopterus notopterus \\
\hline
\end{tabular}

Efforts have been made recently in bringing together the studies of fish diversity in various parts of the southern Western Ghats. The Western Ghats, while being extremely richness in its fish biodiversity has been investigated with regards to species distribution (Bhat, 2003).

\section{CONCLUSION}

The present study largely focuses on fish species richness of Kurikotta Bridge Bennithora River. Due to multiple uses of fisheries resources, fishing has become a major industry and a large number of these aquatic communities are under a big threat of extinction. Habitat loss and environmental degradation has seriously affected the fish fauna. Knowledge 
of available resources and the biological characters of species serve the base line information for further studies on resources conservation and maintenance. Further there is a need for survey of diversity of fish fauna in different types of habitats all over the country. Industrial effluents and man made pollutants also contribute towards the distribution in the balance on aquatic ecosystem. The work will provide future strategies for development and fish conservation.

\section{Reference}

[1] Bhat A., Environmental Biology of Fishes 68 (2003) 25-38.

[2] Day F. (1958). The fishes of India, being a natural history of the fishes known to inhabit the seas and freshwater of India, Burma and Ceylon, text and atlas, London, William Dawson and sons 1td., p. 195-198.

[3] Day F. (1967). The fishes of India, Vol.1 and 2 Jagamander agencies, New Delhi.

[4] Day F. (1889). The fauna of British India including Ceylon and Burma, fishes: 1:548 and 2:509. London, Taylor and Francis.

[5] Jayram K.C. (1981). The freshwater fishes of India. ZSI, 1-438.

[6] Jayram K.C. (1999). The freshwater fishes of the Indian region. Narendra publishing house. Delhi-551.

[7] Mittermeier R.A., C.G. Mittermeier (1997). Mega diversity: earth's biologically wealthiest nation. In: Mcallister, D.E., A.L.Hamilton and B.Harvery (Eds.). Global freshwater biodiversity, sea wind, cervix, Mexico cilg, 11:1-140.

[8] Nelson (1976). Fishes of the world. $3^{\text {rd }}$ edn.john Wiley and sons, New York, p. 416.

[9] Talwar P.K., Jhingran A. (1991). Inland fishes of India and adjacent countries. Oxford and IBH publishing co. New Delhi.1 and 2: 115-116.

[10] Vijaylaxmi C. (2010). A study of the diversity and ecology of freshwater fishes of four river systems of Gulbarga district, Karnataka. Ph.D. Thesis, Gulbarga University, Gulbarga. 